\title{
Building design history. Estonian Museum of Applied Art and Design
}

Estonian Museum of Applied Art and Design (EMAAD) presents an interesting case in Estonian design history from several aspects including the reception of applied art and design in the Soviet Union, as well as institutional changes related to it from the mid1950 onwards.

Relying on the example of the EMAAD I will give an overview of how and in which context developed the ideas of finding and building up a museum focused on collecting and preserving material related to applied art and design. The starting point for this contextualisation lies in the institutional system of Soviet art. I will follow the changing attitudes towards applied art and design over the course of time in order to explain how these processes played a role in the formation of the museum and its collections. If in the 1950 discussions on the reorganisation of everyday life were based on handicrafts and applied art, then from the mid 1960s however industrialisation and the changed course in the production of mass consumer goods brought to the centre the notions of industrial art and design.

Parallelly with these processes in the society, there emerged discussions on the necessity to establish a museum specialized on applied art, discussions that were related to applied art becoming a popular genre in representing Estonian culture in the all-Soviet exhibitions, from the second half of the 1950 s onwards. The rigid separation between applied art and design that emerged in the 196os, led to the institutionalisation of applied art (the museum becoming one of the means for this) and a general neglect of design during the late-Soviet period. It is only in the late 1990 s and early 2000 , that design has re-appeared as a popular subject in the society, allowing now to take a new look also at the material from the Soviet period.

keywords applied art, design, Soviet Estonia, industrial art, design museum

\section{Introduction}

As one of the first ones of its kind in the Soviet Union, The Museum of Applied art was founded in November 1971 as a branch of the Estonian State Art Museum and opened its doors to the audience with a permanent exhibition in summer 1980 - the year of the Regatta of the Moscow Olympics taking place in Tallinn. (Fig. 1)

It was a time when the State Art Museum was developing subdivisions for specific art fields to be available for the broadest audience. Also, it was a time of many cultural institutions being housed in the buildings of the Old Town so the museum moved to a 3-storey former 17th Century granary that was restored and adapted for the purposes of 
the museum, with huge vaulted exhibition spaces and storages to be added later. By that time the collection included around 7000 objects.

Regular temporary exhibitions were organised from 1982 onwards ranging from solo shows to displays of specific fields or survey exhibitions.

Applied art had been part of Estonian Art Museum's collections already from its founding date in 1919 although these collections were formed spordically. At that time it included works of ceramics, leather and textile etc. This pre-war collection suffered in most part from the II World War, with the textile collection completely destroyed when the temporary location of the collection was hit by a bomb. (Tarbekunstimuuseum 1982:3) Active and systematic collecting of applied art in the State Art Museum started in the 1950s, in 1957 the applied art collection was established at the State Art Museum laying grounds for the present day collections.

Until the turn of the century the priority of the Applied Art Museum's collecting policy was Estonian professional applied art, focusing mainly on the unique pieces.

The collection was for a long time (during the Soviet period) formed by the state-directed and supported purchases, selected mainly from the annual survey exhibitions by a commitee of experts at the Ministry of Culture and Art Fund (Artist's Union's subsection) consisting of the representatives from the ministry, party (central committee), museum and artists. Sometimes works were also commissioned directly for the collection. From 1990 s the selection of acquisitions has been made by the museum curators who have at their disposal a small budget for historical material and financial support from the Estonian Cultural Endowment to acquire contemporary material.

The year 2001 marks the foundation of the design collection. Preceeding that year, material on product design in the collections had been scarce: there were some examples from the various enterprises of the pre-war independence period and some examples of serially produced pieces from the Art Product's factory - a body of workshops from the Soviet period to which I will return a little later.

The aim of the newly found design collection was to concentrate on systematic collecting and research of product design and design related material that appeared to be a blank spot on the map of Estonian material culture and cultural heritage, and had been left out from the collections of other museums.

For the historical part of product design, 1990s had seen the privatisation as well as bankrupcy of several of the Soviet period state owned enterprises and factories, and it was importnat to attempt to save their remaining archives and conduct interviews with artists who had worked there in the past. Some of the artists whose unique pieces were included to the collections had earlier been working also for the industry.

At the moment the collection of the museum is around 15.000 museum objects of local unique applied art, product design pieces and different kind of archival material (documents, manuscripts, photos, sketches etc).

\section{Art and Products}

In order to understand the timing and development of the idea and choices made when building up this institution, I would like to slightly try to open up the background of these processes by explaining the position of applied art and design in Estonia at that time. 
in the 1950s, while being incorporated as a brach to the State Art Museum. It was the early Soviet era, the time of propagandist slogans about fulfilling the needs of inhabitants, the need to improve the living standards, supply the population with more products, later also "with more beautiful products" (Rohkem 1953:3) and other similar specific rhetoric. Related to that, the position of the art fields that really were affecting and shaping the everyday environment, became considered highly important. Integrating art into everyday life, making art part of life patterns, available for people, was seen as an ideal to aim for. By mid-1950s, raising the welfare of the population was one of the central topics in the Soviet society. One of the tasks in this that was often quoted, was the improvement of the selection and design features of mass consumer goods. In initial discussions in the 1950s, it was applied art that had to play a role in redefining the new everyday life, in providing a model for "good taste" but also design. For this, it was considered important for the applied artist to collaborate with industry. (Külv, Reemets 1954:6)

This had to be carried out by the applied artist who traditionally had been trained at the State Art Institute (previously State Applied Art School) as specialists for industrial production, working for already existing or potential future factories. Discussions at that period revolved around the need to engage the applied artist more to the process of production and that the failure to do so was seen in shops and in industrial products. The same discussions continued in later years: industry was blamed for using artists only temporarily, the artist had to cooperate with production to raise the selection. (Vaher 1964:27)

From 1950 artists were sent to production facilities and factories on regular basis. By the beginning of 1960 s there were more than 100 artists working in factories as industrial artists, a number that was constantly growing. Another possibility for an applied artist to work besides the industry or as a freelancer, was at the Art Products Factory (combinat) that was considered as a basis and an excellent model for high-quality production, although these often remained only in the form of prototypes. (Vaher 1964:28)

The Art Products Factory was found right after the II World War in Tallinn, when several decorative arts workshops from the 1920 s and 30 s were nationalised and reorganised under the supervision of the Applied Arts Centre of Estonian SSR. These were comparatively small artist studios where most of the work was done by hand but their technical skills allowed for a high quality production that had also been successful in foreign markets. Now these workshops became a basis for a new production model, often using the same premises, applying same skills, tools and people. (Lobjakas 2013:292) The Art Products Factory was functioning under Estonian Artists' Union, that in turn was a branch of the Artists' Union of the USSR.

According to its statute, the Art Products Factory was an ambitious endeavour with a wide scope of activities under one umbrella organisation. It had to provide suitable conditions for artists' to work, popularise their output and implement the art samples produced in workshops to industrial production. The Artists' Factory also opened shops, called salons, for the sales of their own work products. The Factory was organised into eight studios, based on the artistic medium, including textile work, (embroidery, lacemaking, carpets), precious metals, other metals, porcelain painting, glasswork, woodcuts, leatherwork, as well as sculpture and decoration (this included interior design and exhibition design).

An additional support system existed from 1960, for artists who were not Factory's fulltime employees but could reproduce their work and sell it through the salons. The only demand was that it could not be unique objets but had to be serially produced (from only 
2-3 to almost 50). These series gained wide popularity and became a major source of income for several artists.

As a kind of a compromise ground, balancing between hand-made, crafts and industry it was considered a company providing high standard output (Rohkem 1953:3), often forming the main body of the applied art exhibitions from where many pieces of work ended up at the museum's collection. (Fig. 2)

Towards the end of the 1950 s and especially in the 1960 s the idea about applied art as leading the way in industrial product design began to face a change. Although applied art and design (the term being industrial art then) were during the following years seen together, their meaning being intertwined, the idea of the need for a special field of study focusing on industrial production did arise. One of the means to achieve this was a focus on reorganizing the education of applied artists who would have more training in technological and economical matters. The focus had to be taken not on unique items, but comfortable and practical mass-produced goods as can be read from the criticism from this period. (Bernštein 1955:5)

\section{Differences of Art and Design}

The long-term aim in integrating artists to factories was the eradication of the difference between a unique product and a mass produced one (Gens 1959). However, in late 1950 s it was stated that the difference between the products seen in exhibition showcases and on shop windows was still too big one. (Kunstnik 1957:2)

Applied art which was so far seen as a platform for a successful industrial product, changed into an elite artistic genre, existing primarily in the form of exhibitions. The reasons for this could have been, in case of the Art Products Factory, the lack of materials that made the production accessible to only a few, high price based on still a large share of handicraft in the production and outdated technological equipment used in industry that forced the artists to compromise, resulting in unsatisfactory solutions in this sphere. This was sustained by a system where artists working in industry hardly exhibited their works in design exhibitions and were thus excluded from the artist union membership as the union accepted only artists who regularly participated in exhibitions. (Gens 1959:3)

If the Art Products Factory acted for some time as a link between industry and unique production being at the same time hand crafted and serial, then from 1964 their works were not allowed any more to applied art exhibitions. (Kuma 1981:46) Products, serial objects were begun to be separated to an exhibition of industrial art, held from 1963, drawing thus a sharp line between the two fields and putting unique objects to a privileged position. If industrial production had for years been included in the domain of applied art, then now it was excluded from it and was considered solely as a product.

The first exhibition of industrial art took place in 1963 at the main exhibition venue in Tallinn, at the 1930 s founded Art Hall. Later on the differentiation was emphasized also in the venue level - taking the industrial art exhibitions to the outskirts of the town, to a special exhibition ground for fairs, turning the exhibition to that of industrial rather than artistic achievements.

The 1963 exhibition was a major manifestation of industrial applied art introducing newest industrial production as well as the works of various recent graduates from the State Art Institute. There were 72 participants from 20 different factories and 33 free-lance decorative artists included. (Soosaar 1963:3) The exhibition was very well received, and 
reviewers considered it to be different from all previous applied art exhibitions.

Criticism of the same exhibition questioned also the role of industry in reproducing applied art and taking it to the masses as this was too simplistic of an idea that unique products could be directly put to mass production. It was emphasized that every industrial product has to be related to its specific productive base and thus the hand crafted objects of the Art Products Factory did not have a potential in becoming industrial products, the series of 200-300 things were just too small. (Vaher 1964:27)

The exhibition also brought up discussions where the artists working in industry were counterpositioned to artists working in the Art Products Factory, seeing the latter to occupy a privileged status.

Interest in the ideological role in industrial arts of the Art Products Factory (later renamed as design department) declined considerably in the II half of 196os. In 1966 the department of industrial art was opened at the faculty of architecture of the State Art Institute which brought a change to the design discourse in Estonia. The III industrial art exhibition in 1969, which exhibited already works of the students from the department, considered Art Products Factory to represent traditional applied art. In their decorative approach they were foremost seen as applied artists who did not fit into the framework of industrial art. (Fig. 3)

There was indeed a perceived difference with the works of the industrial art department students who presented their compositional exercises and works done in design classes. The studies in the department focused on the environment as a whole, starting from surface texture, formal structure and exercises in proportioning to form- and modelmaking, laying an emphasis on the role of the object in a wider spatial system. (Olep 1972:9) There was a difference between the applied artists and designers in their approach to form, functionality and decoration. The new design professionals got a lot of positive feedback for their work, which was seen as an optimistic beginning for a new practice.

However, this work did not find its way to the museum that acquired its objects through the system fixed by the Artists' Union.

By that time the two fields that were earlier seen together had departed into two different directions. As for applied art by the end of the 1960s, the situation was quite comfortable as the interest in it was remarkable and the output was really purchased and collected. Despite the criticism, by 1971 the agreement on founding the museum was signed. What the discussions throughout the late 1950 and 1960 s reveal is how applied art and industrial design initially developed together, with applied art functioning as the means to give rise to product design, However, with a planned economy based on quantity and a constant shortage of mass consumer goods, the work of industrial designers was nonsignificant or even not needed. Even more, a strong and well functioning art infrastructure (artist unions, art fund) produced the means for applied artists to produce
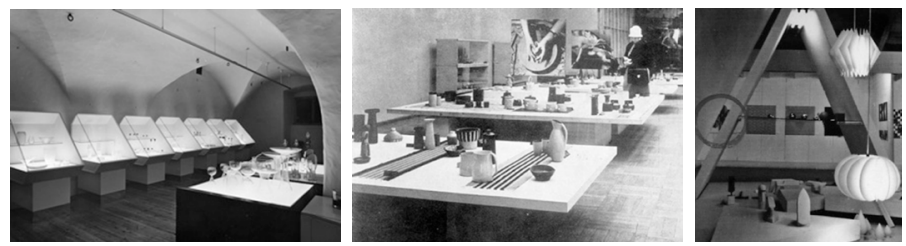

Figure 1 (left),

View to the permanent disaplay at the Estonian Applied Art Museum. 1980.

Figure 2 (center) Exhibition of industrial art at Tallinn Art Hall. 1963.

Figure 3 (right). Exhibition of industrial art in Tallinn. 1969. 
their work in small series and sell them in art galleries and simultaneously enjoy the privileges and visibility that accompanied the membership in the Artists' Union. Thus, applied art gradually approached figurative art and industrial art became more anonymous but also neglected. Industrial art had become a field related to consumption and considered, due to constant compromises between the designer and producer, of no high artistic quality. The latter was thus from the collecting point of view left on a no-mans-land (there was no system to support it as there was for applied art).

\section{New Beginnings}

The beginning of the present century saw quite a change in understanding design as a specific field and also a raise of interest in it differing from the Soviet period. As a young post-soviet country with many shifts in value systems it became an attractive subject. In February 2004 the Museum of Applied Art was renamed to Estonian Museum of Applied Art and Design (similar changes can be detected also in other countries and institutions: Latvian and Finnish Design Museums, Estonian Art Academy's previously applied art departments were renamed design departments, applied artists indentifying themselves as designers etc) and started operating as an independent state museum under the administration of the Estonian Ministry of Culture with a clear vision towards working with historical and contemporary (product) design material.

The aim of building up the design collection at the museums was to gather up materials related to pre-war and contemporary design, the main goal for years has been to put together the puzzle picture of the soviet period Estonian design. By now there are many valuable sub-collections of companies, products, exhibitions, related experimental projects etc. By bringing together these different fields and sides of design, we have a strong a good basis for further research and exhibitions.

\section{References}

Bernštein, B. (1955) 'Kasvatada ja rakendada noori. Märkmeid tarbekunsti konverentsilt'. Rahva Hääl 14.06, p. 6.

Gens, L. (1959) 'Tarbekunst ja elu nõuded'. Sirp ja Vasar 2.10.1959, p. 3.

'Tarbekunstimuuseum. Ekspositsiooni juht'. (1985). Tallinn: Perioodika

'Rohkem maitsekaid tarbeesemeid elanikkonnale'. (1953) Sirp ja Vasar, 21.08, p. 3.

Külv,E, Reemets, E. (1954) 'Kunstilise kvaliteedi huvides'. Sirp ja Vasar 10.05, p. 6.

Vaher,I. (1964) 'Mõtisklusi tööstuskunstist'. Almanahh Kunst no 1, p. 27.

Lobjakas, K. (2013) 'Muutuvad lähenemised. Tallinna Kunstitoodete Kombinaat ja eesti tarbekunsti positsioneerimine 1950.-1960. aastatel', Proceedings of the Art Museum of Estonia. Art and Political Reality, 3(8), pp. 287-308.

'Kunstnik, kunstinõukogu ja tööstusettevõtted'. (1957) Rahva Hääl 01.08., p. 2.

Kuma, H. (1981) 'Elgi Reemets'. Tallinn: Kirjastus Kunst

Gens, L. (1963) 'Elulise suunitlusega'. Rahva Hääl, 13.10., pp. 4-5.

Soosaar, M. (1963) 'Tarbekunstnik ja tööstustoodang'. Õhtuleht 22.10., p.4.

Olep, J. (1972) 'Pilguga tulevikku. Vastab ERKI disainikateedri juhataja dotsent Bruno Tomberg', Sirp ja Vasar, 04.08., p. 9. 